\title{
KAJI EKSPERIMENTAL PANAS KONDENSOR AC SPLIT DENGAN VARIASI PUTARAN FAN UNTUK PENGERINGAN PADI
}

\author{
Yudhy Kurniawan', Kusnandar ${ }^{2,3}$, Yusup Nur Rohmat ${ }^{4}$, Wardika \\ ${ }^{1,3,5}$ Program Studi Teknik Pendingin dan Tata Udara, Politeknik Negeri Indramayu \\ ${ }^{2}$ Department of Refrigeration, Air Conditioning and Energy Engineering, National Chin-Yi University of \\ Technology, Taichung, Taiwan \\ ${ }^{4}$ Program Studi Teknik Mesin, Politeknik Negeri Indramayu \\ 1,4,5 Jl. Raya Lohbener Lama No.8, Indramayu \\ ${ }^{2}$ No.57, Sec.2, Zhongshan Rd, Taiping Dist., Taichung City 41170, Taiwan \\ Email: ${ }^{1}$ k.yudhy@yahoo.com, ${ }^{2,3}$ kusnandar@polindra.ac.id, ${ }^{4}$ yusupnurrohmat@ gmail.com, \\ ${ }^{5}$ wardika@polindra.ac.id
}

\begin{abstract}
Abstrak
Penggunaan Air Conditioning (AC) Split yang biasanya dipakai untuk keperluan pengondisian udara untuk kenyamanan, pada penelitian ini $A C$ Split juga dimanfaatkan untuk pengeringan padi. Pengeringan padi dengan menggunakan $A C$ Split ini merupakan jenis pengerinagn buatan yang mempunyai kelebihan dibanding dengan pengeringan alami yaitu waktu pengeringan yang lebih singkat. Pada AC Split udara panas yang dihasilkan dari kondensor yang dibuang ke lingkungan secara percuma akan dialirkan melalui sebuah saluran udara untuk dimanfaatkan untuk pengeringan padi. Pemanfaatan panas kondensor ini dilakukan untuk untuk mengetahui pengeringan padi dengan menggunakan variasi pengaturan kecepatan fan kondensor. Pada $A C$ Split dilakukan untuk mengetahui laju pengeringan padi dengan kecepatan putaran fan sebesar $450 \mathrm{rpm}$ dan $800 \mathrm{rpm}$. Dari hasil data yang didapatkan selama 1,5 jam pada proses pengeringan padi diperoleh besarnya kadar air pada padi berkurang sekitar $8 \%$ dan $12 \%$ untuk putaran fan kondensor $450 \mathrm{rpm}$ dan $800 \mathrm{rpm}$. Adapun temperatur udara tertinggi dihasilkan panas dari kondensor adalah sebesar $53,6{ }^{\circ} \mathrm{C}$, dengan kelembaban relatif (Relative Humidity) adalah sebesar $15 \%$.
\end{abstract}

Kata Kunci: Pengeringan padi, AC Split, Panas kondensor, putaran fan

\begin{abstract}
The use of Split of Air Conditioning (AC) which is usually used for air conditioning for human convenience. In this study a split AC was used for drying rice. Rice drying using Split AC is a type of artificial drying that has an advantage compared to natural, which is shorter drying. In Split AC the hot air generated from the condenser released into the environment is useless will be flowed through the air duct to be used for drying rice. The use of condenser heat is carried out to find out how to grow rice by using variations in the condenser fan speed regulation. In Split AC, it is done to find out the flow of drying with a variation fan rotation speed of $450 \mathrm{rpm}$ and $800 \mathrm{rpm}$. From the results of the data experiment for taking around 1.5 hours in the drying process obtained moisture content is $8 \%$ and $12 \%$ for the 450 rpm and $800 \mathrm{rpm}$ condenser fan rotation each. Although the temperature of the air produced by the condenser heat is $53.6^{\circ} \mathrm{C}$ and $50.6^{\circ} \mathrm{C}$. The other data of relative humidity of the air (Relative Humidity) is $15 \%$.
\end{abstract}

Keywords: Rice driyer, Split AC, condenser heat, fan rotation 


\section{PENDAHULUAN}

\section{I.1 Permasalahan Penelitian}

Pengeringan adalah proses pemindahan atau pengeluaran kandungan air hingga mencapai kandungan air tertentu agar kecepatan kerusakan bahan dapat diperlambat. Proses pengeringan ini dipengaruhi oleh suhu, kelembaban udara lingkungan, kecepatan aliran udara pengering, kandungan air yang diinginkan, energi pengering, dan kapasitas pengering (Kurniawan, Ruslani, \& Anggriawan, 2017)

Pengeringan pada padi merupakan proses pengurangan kadar air yang terkandung didalam padi pasca panen. Penanganan pasca panen yang dilakukan para petani khususnya di Indramayu pada proses pengeringan padi masih dilakukan dengan menggunakan cara-cara konvensional seperti menggunakan lantai jemur dengan sumber energi dari sinar matahari. Secara ekonomis, pengeringan dengan sistem penjemuran ini memang murah dan tidak memerlukan peralatan mekanis lain. Namun demikian, banyak keterbatasan yang menyertai seperti membutuhkan lahan untuk pengeringan yang luas, memerlukan banyak tenaga kerja, sangat tergantung pada kondiusi cuaca di siang hari karena apabila terjadi cuaca mendung atau hujan sudah bisa dipastikan pengeringan ini tidak bisa dilakukan, mudah terkontaminasi kotoran atau partikel lain kartena dilakuan di lingkungan tempat terbuka, serta temperatur dan kelembaban tidak bisa dikondisikan, dan lain-lain. Keterbatasanketerbatasan tersebut telah mengakibatkan padi yang di keringkan menurun kualitasnya.

Kondisi semacam ini telah menuntut untuk dapat dilakukannya proses pengeringan secara cepat, penerapan proses pengeringan secara mekanis menggunakan peralatan atau mesin pengering (mechanical dryer) dengan metode operasional yang murah dan efisien sangat dibutuhkan oleh petani yang bisa membantu dalam pengeringan padi apalagi musim penghujan. Pengeringan padi menggunakan mesin pengering padi dapat menghasilkan gabah kering lebih baik sebesar 2-3\% (Nugraha, Thohir, Lubis, \& Sutrisno, 2007)

Pada saat ini masyarakat sudah banyak yang menggunakan AC split namun masih banyak pula yang belum memanfaatkan energi panas buangannya. Pemanfaatan kalor yang dibuang oleh kondensor AC split ini salah satunya bisa dimanfaatkan untuk mengeringkan padi/gabah pasca panen. Pada kali ini penulis melakukan analisa perbandingan terhadap putaran fan pada kondensor AC Split dengan kecepatan fan high\&low. Dengan perbandingan tersebut mana yang lebih efesien untuk kondensor AC Split dalam mengeringkan padi.

\section{I.2 Wawasan dan Rencana Pemecahan Masalah}

Berdasarkan latar belakang tersebut diatas, masalah yang akan diselesaikan menitikberatkan pada proses pengeringan gabah padi dengan menggunakan AC Split ramah lingkungan dengan metode sistem menggunakan panas kondensor.

\section{I.3 Rumusan Tujuan Penelitian}

Pengeringan gabah padi dengan memanfaatkan panas kondensor sebagai heat recovery dengan menggunakan AC Split bertujuan untuk mempercepat pengeringan padi yang selama ini petani hanya mengandalkan panas matahari.

\section{I.4 Kajian Teoritik}

AC Split merupakan salah satu mesin pengkondisi udara yang bekerja dengan siklus kompresi uap. Siklus kompresi uap merupakan salah satu siklus yang digunakan untuk sistem refrigerasi mekanik, dimana uap refrigerant akan dikompresi oleh kompresor sebagai komponen utama disamping komponen lainnya seperti kondensor, katup ekspansi dan evaporator. Kondensor akan mengeluarkan udara panas sedangkan evaporator akan mengeluarkan udara dingin. Dalam kajiannya panas buang dari kondensor dimanfaatkan untuk pengeringan padi. Manfaat dari alat ini diharapkan mampu memberikan solusi alternatif untuk mempercepat proses pengeringan pada padi sehingga menghasilkan produktifitas bagi petani.

\section{TINJAUAN PUSTAKA}

Penelitian mengenai pemanfaatan AC Split dengan memanfaatkan panas buang dari kondensor serta mengatur suhu dan kelembaban udara untuk pengeringan padi telah berhasil dilakukan. Sistem ini menghasilkan benih padi dengan kadar air $11 \%$ setelah proses pengeringan selama 10 jam. Pengaturan suhu menggunakan kipas exhaust bekerja dengan baik selama proses pengeringan yang diatur pada rentang temperatur $30-43^{\circ} \mathrm{C}$, sedangkan pengaturan kelembaban udara menggunakan blower dapat dipertahankan dengan nilai kelembaban udara diatas $42,55 \%$ (Indarto, Puspitasari, \& Sunarno, 2017)

Proses pengeringan padi yang lain dengan cara mengalirkan kecepatan udara sebesar $13 \mathrm{~m} / \mathrm{s}$ dengan 
jumlah pipa pemanas sebanyak 2 buah telah dilakukan (Kana, Tarigan, \& Maliwemu, 2016). Untuk AC Split dengan kapasitas 1PK atau setara dengan $745 \mathrm{~W}$, didapatkan dari hasil penelitian besarnya temperatur kondensor maksimal adalah $69,9^{\circ} \mathrm{C}$ sedangkan temperatur minimal adalah $61,5^{\circ} \mathrm{C}$. dengan nilai kalor laten rata-rata sebesar $0,23868 \mathrm{~kJ} / \mathrm{s}$ dan nilai kalor sensible rata-rata sebesar $1,75032 \mathrm{~kJ} / \mathrm{s}$ sehingga nilai kalor total pada kondensor adalah sebesar $1,989 \mathrm{kj} / \mathrm{s}$ (Kusnandar, Rohmat, \& Kurniawan, 2018). Disisi lain telah didapatkan bahwa energi yang dihasilkan oleh panas kondensor yang dibuang sebesar $0,68 \mathrm{~kW}$ dengan besaran COP pada AC split sebesar 5,25 (Hermawan, \& Mulia, 2015).

AC Split memiliki potensi sebagai sumber panas untuk alat pengering mekanis, diantaranya pernah dilakukan penelitian untuk pengering di musim dingin (Peng, Gong, Deng, Liang, \& Li, 2020). Metode pemanasan udara pada AC Split juga pernah dilakukan dengan pengaturan heating mode (Han, yan, \& Yu, 2019).

\section{METODE}

Perancangan alat sebelum dilakukan pembuatan alat penelitian terlebih dahulu harus menentukan spesifikasi atau rancangan dari alat mesin pengering padi dengan menggunakan AC Split kapasitas $1 \mathrm{Pk}$. Adapun spesifikasi dari AC Split yang akan digunakan dalam penelitian ini mempunyai spesifikasi teknis yang dapat dilihat pada Tabel 1seperti dibawah.

Tabel 1. Spesifikasi Teknis AC Split

\begin{tabular}{|l|c|}
\hline Model & AU=A9KLY \\
\hline Voltage [V] $/[\mathrm{Hz}]$ & $220 / 50$ \\
\hline Capacity [Btu/hr] & $9000 \mathrm{Btu} / \mathrm{hr}$ \\
\hline Input Power [W] & $745 \mathrm{watt}$ \\
\hline Current [A] & 3,50 \\
\hline Refrigerant & $\mathrm{R} 22$ \\
\hline Kapasitas Refrigerant & $0,46 \mathrm{~kg}$ \\
\hline
\end{tabular}

Pembuatan mesin pengering padi ini menggunakan pemanfaatan panas pembuangan dari kondensor, maka AC Split yang digunakan akan ditambahkan saluran udara untuk mengalirkan udara panas (ducting) dari kondensor. Gambar 1. menunjukkan gambar rancangan skematik yang akan dibuat untuk penelitian dengan tambahan peralatan seperti terlihat.

Pada Gambar 1, kabin untuk ruang pengering padi berbahan plat alumunium dengan ketebalan $0,3 \mathrm{~mm}$ berdimensi panjang $50 \mathrm{~cm}$, lebar $50 \mathrm{~cm}$ dan tinggi $45 \mathrm{~cm}$. Saluran udara atau ducting berbahan acrilic dan plat alumunium. Tabung atau silinder sebagai penyimpanan padi di dalam kabin berbahan plat alumunium dengan ukuran diameter $30 \mathrm{~cm}$ dan tinggi $32 \mathrm{~cm}$. Mengingat mesin pengering padi ini menggunakan pemanfaatan panas pembuangan dari kondensor, maka analisis kinerja mesin tersebut dengan mengalirkan udara panas pembuangan dari kondensor kedalam kabin melalui saluran udara / ducting.

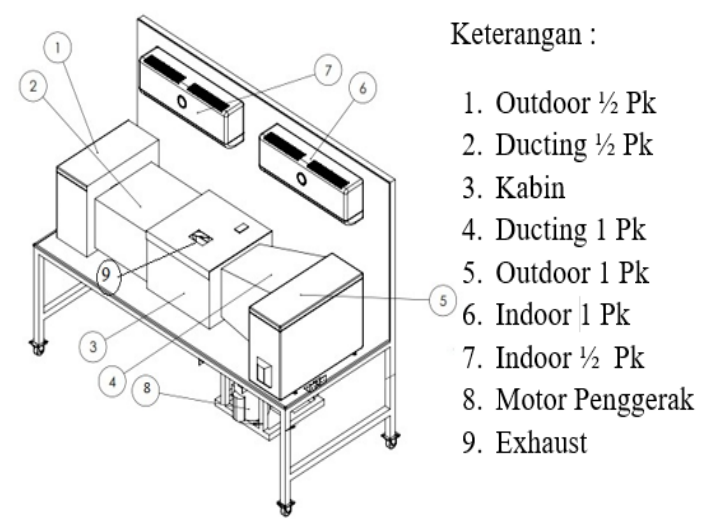

Gambar 1. Gambar Skematic

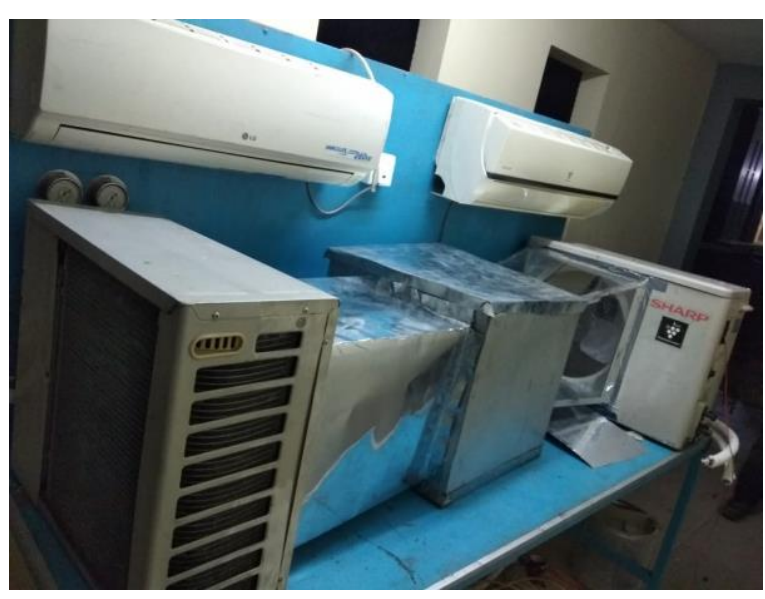

Gambar 2. Alat Pengeringan Padi menggunakan AC Split

Pada Gambar. 2. Menunjukkan alat pengering padi dari AC Split dengan memanfaatkan panas kondensor yang dibuat dengan penambahan saluran udara (ducting) untuk mengalirkan udara panas untuk proses pengeringan. Terlihat pada gambar. 2 . terdapat 2 (dua) AC split, akan tetapi pada penelitian ini yang akan dianalisa hanya menggunakan 1 (satu) unit AC split dengan kapasitas $1 \mathrm{Pk}$.

Dalam proses pengambilan data dilakukan pada saat pengujian unit sistem pengeringan menggunakan panas kondensor pada AC Split. Dalam waktu pengambilan data dilakukan setiap 5 menit sekali selama 90 menit atau 1,5 jam untuk 
Alat pengeringan padi menggunakan AC Split $1 \mathrm{PK}$. Untuk data yang diambil yaitu antara lain:
a) Temperatur udara $I N, O U T$ dan $R H$ pada kondensor
b) Temperatur dan RH pada kondensor
c) Temperatur dan RH pada kabin
d) Kecepatan putaran fan kondensor
e) Kecepatan aliran udara kondensor

\section{HASIL DAN PEMBAHASAN}

Dari hasil pengambilan data pada alat pengering padi ini didapat grafik seperti terlihat pada Gambar 3 dibawah. Dari pengukuran diperoleh data nilai temperatur udara yang dihasilkan untuk temperatur saluran udara (ducting) yaitu sebesar $53,3{ }^{\circ} \mathrm{C}$ dan temperatur kabin yaitu sebesar $53,6{ }^{\circ} \mathrm{C}$. Temeperatur yang didapat hampir sama dengan nilai temperatur udara keluaran kondensor selama 1,5 jam alat pengering padi tersebut dijalankan. Adapun kecepatan putaran fan kondensor diatur sebesar $450 \mathrm{Rpm}$. Nilai temperatur udara tersebut yaitu berkisar antara $50,3^{\circ} \mathrm{C}$ s.d $53,6^{\circ} \mathrm{C}$. sedangkan untuk temperatur lingkungan yang didapat dari hasil pengukuran yaitu berkisar antara $31,5^{\circ} \mathrm{C}$ s.d 32,7 ${ }^{\circ} \mathrm{C}$.

Dari Gambar 4 seperti dibawah terlihat bahwa kelembaban udara masuk ke kondensor selalu lebih besar daripada udara kelua. Hal ini dikarenakan terjadinya perpindahan panas dari udara melalui pipa kondensor yang didalam nya terdapat fulida refrigerant yang mempunyai temperatur lebih tinggi dari temperatur lingkungan. Sehingga temperatur refrigerant yang lebih tinggi ini akan menyebabkan berkurangnya berkurangnya kelembaban udara. Dari grafik terlihat kelembaban udara yang memasuki kondensor sekitar 55\% sedangkan keluar kondensor kelembabannya menjadi $15 \%$. Pengambilan data yang dilakukan untuk mengukur kelembaban udara ini selama 1,5 jam dan data-data yang diambil setiap 5 (lima) menit sekali jadi keseluruhan data yang didapat semuanya sebanyak 18 (delapanbelas) kali pengambilan data.

Dari Gambar 5 dibawah terlihat grafik kecepatan udara dengan variasi putaran fan sebesar $800 \mathrm{Rpm}$ dan $450 \mathrm{Rpm}$. Pada putaran fan $800 \mathrm{Rpm}$ terlihat pada grafik lebih besar kecepatan udaranya dibandingkam dengan $450 \mathrm{Rpm}$. Dari grafik didapat kecepatan udara pada putaran fan $800 \mathrm{Rpm}$ lebih besar 20\% kecepatan udara dari 450 Rpm. Kecepatan udara tertinggi pada $800 \mathrm{Rpm}$ adalah sebesar $2,8 \mathrm{~m} / \mathrm{s}$ sedangkan pada putaran fan 450 Rpm adalah sebesar 2,3 m/s.

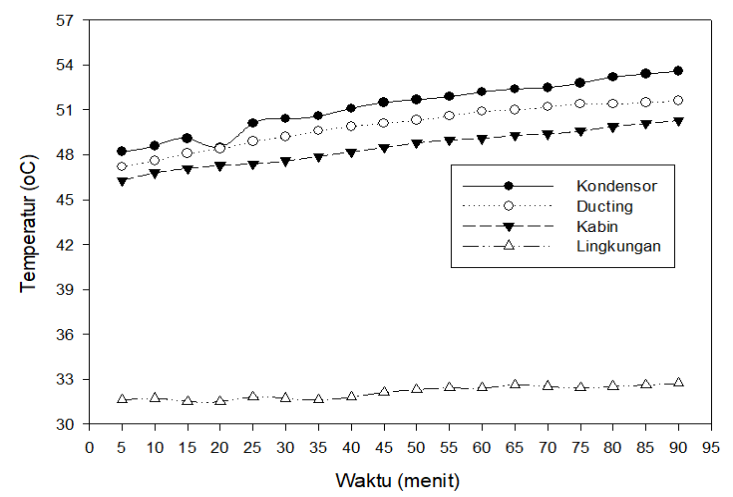

Gambar 3. Grafik temperatur udara keluaran dari system

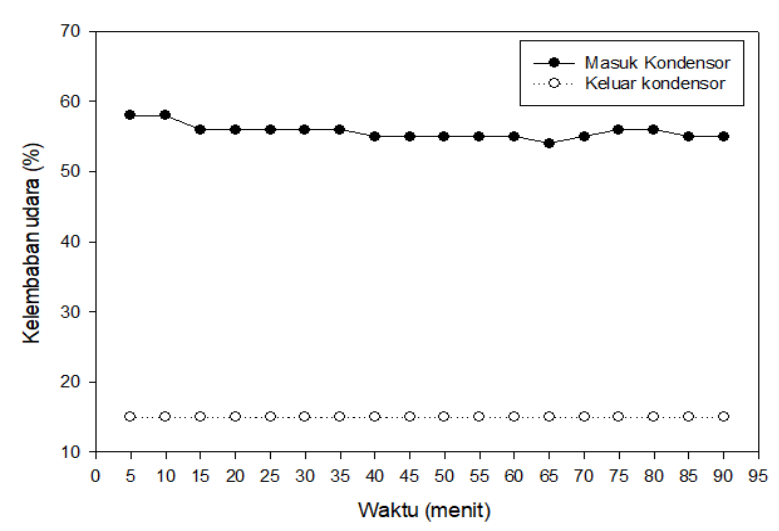

Gambar 4. Grafik kelembaban udara (RH \%) masuk dan keluar kondensor

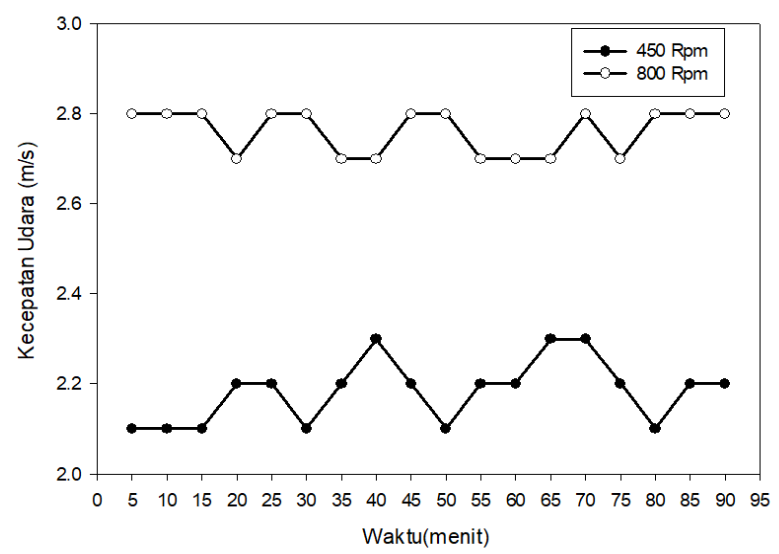

Gambar 5. Grafik kecepatan udara (RH \%) masuk dan keluar kondensor dengan variasi putaran fan

Untuk menghitung kadar air yang terkandung dalam proses pengeringan padi bisa menggunakan persamaan seperti dibawah. Kandungan air pada padi dapat dinyatakan dalam wet basis atau dry basis. Kandungan kelembaban dalam wet basis menyatakan perbandingan massa air dalam bahan dengan massa total baha. Pada dry basis, kandungan air dihitung dengan membagi massa air dalam kandungan padi dengan massa keringnya saja. Kandungan baik 
wet basis dan dry basis dinyatakan dalam persen kelembaban.

$$
\begin{array}{r}
M w=\frac{m w}{m w+m d} \\
M d=\frac{m w}{m d}
\end{array}
$$

Dimana

$$
\begin{array}{ll}
\text { Mw } & =\text { Wet basis } \\
\text { mw } & =\text { massa air } \\
\text { md } & =\text { massa kering bahan } \\
\text { Md } & =\text { Dry basis }
\end{array}
$$

Massa padi sebelum pengeringan $2,5 \mathrm{Kg}$ dan massa padi setelah pengeringan menggunakan panas kondensor selama 1,5 jam (90 menit) menjadi 2,3 kg. Dengan menggunakan kecepatan putaran fan kondensor 450 RPM 450 laju pengeringannya sebesar:

Laju Pengeringan $=$ Masa awal - Masa Akhir

$$
\begin{aligned}
& =2,5-2,3=0.2 \mathrm{~kg} \\
& =0,2 \mathrm{Kg}
\end{aligned}
$$

Dikarenakan proses pengeringan dilakukuan selama 90 menit (5400 detik), maka laju pengeringan uap air pada padi tersebut adalah

$$
\begin{aligned}
& =0,2 \mathrm{~kg} / 5400 \mathrm{~s} \\
& =0,0000370 \mathrm{~kg} / \mathrm{s}
\end{aligned}
$$

Jadi dalam pengeringan selama 1,5 jam (90 menit) kadar air yang terbuang dari dalam padi sebesar $0,2 \mathrm{~kg}$, berarti dalam perdetik air yang terbuang adalah $0,0000370 \mathrm{~kg} / \mathrm{s}$.

Sedangkan dalam menghitung persentasi kadar uap aie tang hilang atau terbuang pada proses pengeringan padi adalah :

$$
\begin{aligned}
\text { Massa uap air }=\frac{(\text { massa awal-massa akhir })}{\text { massa produkawal }} \times 100 \% \\
=\frac{2,5 \mathrm{~kg}-2,3 \mathrm{~kg}}{2,5} \\
=\frac{0,2}{2,5} \times 100 \% \\
=8 \%
\end{aligned}
$$

Sedangkan untuk pengeringan padi menggunakan putaran fan $800 \mathrm{Rpm}$ didapatkan massa padi sebelum pengeringan $2,5 \mathrm{Kg}$ dan massa padi setelah pengeringan menggunakan panas kondensor selama 1,5 jam (90 menit) menjadi 2,2 kg. Dengan menggunakan kecepatan putaran fan kondensor 800 RPM 450 laju pengeringannya sebesar:

Laju Pengeringan $=$ Massa awal - Massa Akhir

$$
\begin{aligned}
& =2,5-2,2 \\
& =0,3 \mathrm{Kg}
\end{aligned}
$$

Dikarenakan proses pengeringan dilakukuan selama 90 menit (5400 detik), maka laju pengeringan uap air pada padi tersebut adalah

$$
\begin{aligned}
& =0,3 \mathrm{~kg} / 5400 \mathrm{~s} \\
& =0,0000556 \mathrm{~kg} / \mathrm{s}
\end{aligned}
$$

Jadi dalam pengeringan selama 1,5 jam (90 menit) kadar air yang terbuang dari dalam padi sebesar $0,3 \mathrm{~kg}$, berarti dalam perdetik air yang terbuang adalah $0,0000556 \mathrm{~kg} / \mathrm{s}$.

Sedangkan dalam menghitung persentasi kadar uap air tang hilang atau terbuang pada proses pengeringan padi adalah :

$$
\begin{aligned}
\text { Massa uap air } & =\frac{(\text { massa awal-massa akhir })}{\text { massa produk awal }} \times 100 \% \\
& =\frac{2,5 \mathrm{~kg}-2,2 \mathrm{~kg}}{2,5} \\
& =\frac{0,3}{2,5} \times 100 \% \\
& =12 \%
\end{aligned}
$$

Sehingga dengan hasil perhitungan yang didapat dari data-data hasil penelitian menujukkan kadar air dalam proses pengeringan padi dengan menggunakan variasi putan fan kondensor sebesar $800 \mathrm{Rpm}$ menghasilkan pengurangan kadar air pada proses pengeringan padi sekitar $12 \%$, sedangkan menggunakan variasi putaran fan sebesar $400 \mathrm{Rpm}$ menghasilkan pengurangan kadar air sebesar $8 \%$. Ini menunjukkan bahwa semakin tinggi putaran fan pada kondensor akan menghasilkan panas udara yang lebih besar. Pada penelitian ini menujukkan bahwa variasi putaran fan kondensor sebesar 800 Rpm dibandingkan dengan variasi putaran fan kondensor sebesar $450 \mathrm{rpm}$ memiliki perbedaan pengurangan kadar air pada pengeringan padi yaitu sebesar sebesar $4 \%$.

\section{PENUTUP}

\section{Kesimpulan}

Berdasarkan pengujian dan perhitungan data yang di peroleh, maka dapat ditarik beberapa kesimpulan sebagai berikut:

1. Berdasarkan perhitungan yang didapat dari datadata penelitian menunjukkan bahwa variasi putaran fan kondensor sebesar $800 \mathrm{Rpm}$ lebih banyak menghilangkan kadar air pada proses pengeringan padi dibandingkan dengan mengunakan variasi putaran fan $450 \mathrm{Rpm}$.

2. Proses pengeringan padi menggunakan panas kondensor dengan variasi putaran fan mampu mengurangi kadar air sebesar $12 \%$ selama 1,5 jam dengan massa padi sebesar $2,5 \mathrm{Kg}$.

3. Temperatur udara kondensor yang dihasilkan oleh Ac split 1 Pk dengan RPM 450 selama 1,5 jam waktu pengeringan berkisar antara $48,3-53,6^{\circ} \mathrm{C}$ dengan kelembaban udara mencapai $15 \%$, kemudian dengan RPM 800 berkisar antara 46,9 - 
50,6 ${ }^{\circ} \mathrm{C}$ dengan kelembaban udara konstan sebesar $15 \%$.

4. Mesin pengering padi ini menggunakan unit ac split yang saat ini masyarakat sudah banyak yang mempunyainya namun masih banyak pula yang belum memanfaatkan panas pembuangan dari kondensor. Pemanfaatan kalor yang dibuang oleh kondensor Ac Split ini salah satunya bisa dimanfaatkan untuk mengeringkan padi /gabah pasca panen. mesin pengering padi ini menggunakan 2 unit Ac split yang diharapkan bisa menjadi perbandingan terhadap 2 unit ac split tersebut. Dengan perbandingan tersebut mana yang lebih efisien untuk kondensor Ac split dalam mengeringkan padi.

\section{Saran}

Penelitian ini masih memerlukan penelitian lanjutan mengingat belum dilakukannya penelitian dengan menggunakan variasi putrana fan yang lebih banyak untuk mendapatkan hasil yang lebih baik lagi. Adapun type AC Split dengan kapasitas yang lain seperti kapasitas $1.5 \quad \mathrm{Pk}$ dan $2 \mathrm{Pk}$ lebih memungkinkan untuk dilakukan penelitian selanjutnya.

\section{Ucapan Terima Kasih}

Ucapan terima kasih saya sampaikan kepada Politeknik Negeri Indramayu (Polindra) yang dalam hal ini telah mendanai dan memfasilitasi kegiatan penelitian dan pengabdian masyarakat ini khususnya kepada Unit P3M (Penelitian Pengabdian Pada Masyarakat) sebagai unit koordinator untuk menangani semua kegiatan penelitian dan pengabdian masyarakat ini di lingkungan internal kampus.

Kepada rekan-rekan dosen dan mahasiswa khususnya di Jurusan Teknik Pendingin dan Tata Udara Program Studi Teknik Pendingin dan Tata Udara yang telah banyak membantu mulai dari pembuatan alat pengering padi sampai selesainya dalam penelitian ini.

\section{DAFTAR PUSTAKA}

Han, B., yan., \& Yu, J. (2019). Refrigerant migration during startup of split air conditioning in heating mode, Apply Thermal Engineering, Volume 148, pp 1068-1073.

Hermawan, I., \& Mulia, M. (2015). Analisis Energi dan Eksergi Pengeringan Pisang Memanfaatkan Panas dari Kondensor AC (Air Conditioner), Jurnal Teknovasi, Volume 2, No. 2, pp.63-72
Indarto, B., Puspitasari, S., \& Sunarno, H. (2017). Pemanfaatan Panas Buang Air Conditioner (AC) pada Lemari Pengering Benih Padi, Jurnal Fisika dan Aplikasinya, Volume 13, No. 3, pp. 119-125.

Kana, M.R., Tarigan, B.V., \& Maliwemu, E. U. K. (2016). Pengaruh Kecepatan Angin Blower dan Jumlah Pipa Pemanas Terhadap laju pengeringan Pada alat Pengering Padi Tipe Bed Dryer Berbahan Bakar Sekam Padi, Lontar Jurnal Teknik Mesin Undana, Volume 3, No. 2, pp. 29-34.

Kurniawan, Y., Ruslani, \& Anggriawan, F.A. (2017). Analisa Kinerja Sistem Heating Dehumidifier Menggunakan AC Split untuk Pengeringan Ikan, Jurnal Teknologi Terapan, Volume 3, Nomor 1, ppl. 41-47.

Kusnandar, Rohmat, Y.N., \& Kurniawan, Y. (2018). Analisa Panas Kondensor Pada AC Split Menggunakan Refrigeran R32, Seminar Nasional Keteknikan (SINTEK), Fakultas Teknik Universitas Khairun, Terrnate, pp.647-655.

Nugraha, S., Thahir, R., Lubis, S., \& Sutrisno. (2007). Analisis model pengolahan padi, Jurnal Enjiniring Pertanian, Vol. 5, pp.13-26.

Peng, P., Gong, G., Deng, X., Liang, C,. \& Li, W. (2020). Field study and numerical investigation on heating performance of air carrying energy radiant air-conditioning system in an office, Energy and Buildings, Volume 209, 109712. 